\title{
Neuropathophysiology, Genetic Profile, and Clinical Manifestation of Mucolipidosis IV-A Review and Case Series
}

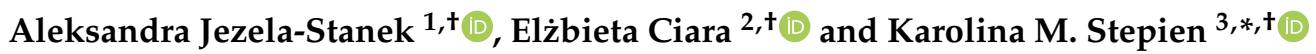 \\ 1 Department of Genetics and Clinical Immunology, National Institute of Tuberculosis and Lung Diseases, \\ 01-138 Warsaw, Poland; jezela@gmail.com \\ 2 Department of Medical Genetics, The Children's Memorial Heath Institute, 04-730 Warsaw, Poland; \\ e.ciara@ipczd.pl \\ 3 Adult Inherited Metabolic Diseases, Salford Royal NHS Foundation Trust, Salford M6 8HD, UK \\ * Correspondence: kstepien@doctors.org.uk \\ + These authors contributed equally to this work.
}

Received: 31 May 2020; Accepted: 23 June 2020; Published: 26 June 2020

\begin{abstract}
Mucolipidosis type IV (MLIV) is an ultra-rare lysosomal storage disorder caused by biallelic mutations in MCOLN1 gene encoding the transient receptor potential channel mucolipin-1. So far, 35 pathogenic or likely pathogenic MLIV-related variants have been described. Clinical manifestations include severe intellectual disability, speech deficit, progressive visual impairment leading to blindness, and myopathy. The severity of the condition may vary, including less severe psychomotor delay and/or ocular findings. As no striking recognizable facial dysmorphism, skeletal anomalies, organomegaly, or lysosomal enzyme abnormalities in serum are common features of MLIV, the clinical diagnosis may be significantly improved because of characteristic ophthalmological anomalies. This review aims to outline the pathophysiology and genetic defects of this condition with a focus on the genotype-phenotype correlation amongst cases published in the literature. The authors will present their own clinical observations and long-term outcomes in adult MLIV cases.
\end{abstract}

Keywords: mucolipidosis type IV; MCOLN1; corneal clouding; gastrin; myopathy; neurodegenerative

\section{Introduction}

Mucolipidosis type IV (MLIV; \#252650), is a rare autosomal recessive lysosomal storage disease (LSD) resulting from loss-of function mutations in the MCOLN1 gene (*605248), which encodes for mucolipin-1 (ML1). This transient receptor, also known as potential channel protein mucolipin-1 (TRPML1), a vesicular $\mathrm{Ca}^{2+}$ release channel belonging to the transient receptor potential (TRP) superfamily [1-3], plays a role in endocytosis, and its dysfunction results in a build-up of lysosome substrates in the cytoplasm [4], aberrations in endosomal and autophagosomal trafficking, modifications to autophagy, abnormal regulation of lysosomal exocytosis, changes in the mammalian target of rapamycin complex 1 (mTORC1)/Transcription factor EB (TFEB) signaling axis, and dysregulation of heavy metal homeostasis [5].

Apart from TRPML1, the TRPML subfamily consists of two other members, TRPML2 and -3 , which are encoded by MCOLN2 and -3 genes, respectively. In humans, these proteins exhibit a common six-membrane-spanning topology. They interact in vesicular trafficking; their exact role in intracellular compartments is not completely understood yet. TRPML2 and TRPML3 have not been linked with any human disease [6].

Mucolipin-1 (ML-1) is a membrane protein consisting of six recognized transmembrane-spanning domains placed at late endosomes and lysosomes; a serine lipase domain and a nuclear localization 
signal $[7,8]$. Two proline containing sequences separate the first two transmembrane domains near the N-terminus, and a di-leucine motif (L-L-X-X) at the C-terminal tails regulate the protein trafficking to the late endosomal pathway [9-11]. Amino- and carboxyl-terminal tails have a cytosolic orientation, and the pore located between transmembrane segments 5 and 6, in the C-terminal half, contains Ser(557), the principal phosphorylation site, and Ser(559) [7,12,13].

The ML-1 channels may be involved in $\mathrm{Ca}^{2+}$ transport across membranes in lysosomes [14,15] in $\mathrm{Ca}^{2+}$-dependent fusion between the lysosomal and plasma membrane during the exocytotic stage of the membrane trafficking process, and in pathophysiological processes concerning lysosomal aggregation, proteolysis, and storage [15]. Lysosomal exocytosis has been shown to play a role in wound healing; membrane repair and cellular debris clearance [16]. Alterations in ML-1 and disturbance in these processes result in the accrual of heterogenous lipids and proteins in vacuoles in cytoplasm [13] and could be implicated in both corneal clouding [17] and achlorhydria [15,18], two hallmarks of MLIV.

\subsection{The Mucolipin (TRPML) Subfamily}

The mucolipins (TRPML) are a subfamily of channel proteins consisting of mucolipin 1, 2, and 3 (TRPML1, TRPML2, and TRPML3, respectively) [19,20].

The MCOLN1 gene, located on chromosome 19p13.2-13.3, containing 14 exons and encoding a 580-amino acid potential channel proteinmucolipin-1 (TRPML1), was first described by Bargal et al. [1]. The protein is confined to the surfaces of late endosomes and lysosomes, in various tissues, with its highest expression documented in the brain, kidney, spleen, liver, and heart [21].

It has been shown that some members of the TPR channel superfamily are critical in sustaining satisfactory ion homeostasis, signaling, and membrane trafficking in endosomes by regulating the concentration of free calcium in cells and $\mathrm{Ca}^{2+}$ efflux from acidic milieu [22].

The regulation of autophagy has also been attributed to TRPML channels. It has been demonstrated in experimental studies that, when TRPML1 is absent in MLIV cells, the autophagy stimulation by TRPML3 is not regulated, resulting in the increased autophagosome formation, as previously shown in MLIV patient cells [7,23-25].

A recent study by Park et al. [26] has highlighted the major role of TRPML1 in guarding against involuntary, pathological fusion between the lysosomes and other intracellular organelles, including the secretory organelles [26]. Importantly, it may significantly impact future therapies of MLIV.

\subsection{Ethnicity}

Mucolipidosis type IV (MLIV) was first described in 1974 in an Ashkenazi Jewish (AJ) infant with congenital corneal clouding and systemic storage bodies [27]. Although $70 \%-80 \%$ of patients with MLIV are of Ashkenazi Jewish and Ashkenazi Polish origin [8], among whom the carrier frequency is reported to be 1 in 100 [8] and a predicted incidence is 1:42.000 [28], patients from all ethnicities have been reported to have similar symptoms and signs worldwide [12]. Identification of biallelic pathogenic variants in MCOLN1 confirms the MLIV diagnosis.

To date, 35 different mutations in MCOLN1 gene have been described in MLIV patients [29] (Supplementary Materials Table S1).

Most of these mutations lead to the creation of a nonfunctional protein or prevent any protein from being produced. Two mutations account for 95\% of all MLIV cases in people with Ashkenazi Jewish ancestry $[1,30]$. The most common (founder) mutation (called major AJ variant), which accounts for $77 \%$, is a splice site c.406-2A>G substitution and introduces a premature termination of the ML-1 translation. The other common mutation, which comprises 18\%, is a large gene deletion c.-1015_789del called minor AJ variant. Approximately $60 \%$ of Ashkenazi Jewish patients with MLIV are homozygous for the major AJ pathogenic variant and $>30 \%$ are compound heterozygotes for both (major AJ and minor AJ) pathogenic variants [31,32]. To date, only one homozygote for the minor AJ mutation has been identified [33]. The major AJ pathogenic variant occurs in only 6-10\% of non-Ashkenazi Jewish 
individuals. It is uncertain how mutations in the MCOLN1 gene result in such distinct (severe to mild) clinical manifestations in patients with MLIV.

\section{Clinical Manifestations}

Mucolipidosis type IV (MLIV) is a neurodevelopmental disorder, which in $95 \%$ of individuals manifests with typical findings, neurologic and ocular, with additional characteristic biochemical parameters. Pregnancy is usually uncomplicated, and infants with MLIV have generally normal development [34]. Children born at term have normal anthropometric parameters. Reduction of normal growth velocity has been previously documented [34]. Growth retardation has been evident in all patients, aged 20 months to 32 years, despite adequate food intake [35]. All these patients had feeding difficulties, failure to thrive, reduced facial movements, constant hypersalivation, and difficulties in swallowing, which according to Chitayat et al. [35], may have indicated cranial nerve involvement (Table 1).

In childhood and during the first two-three decades of life, the neurologic course of the disease is stable, akin to cerebral palsy; spastic diplegia or quadriplegia are frequent diagnoses [33,36].

Specific clinical and laboratory features are discussed in the article below.

\subsection{Dysmorphic Features}

Although rare, craniofacial dysmorphism and congenital anomalies have been previously described [12,35-38].

Riedel et al. (1985) observed mild facial dysplasia with full lips, tooth anomaly, and large, low-set ears, with prominent earlobes in a 17-year-old patient [37]. Another patient presented with "trigonocephaly with a narrow bitemporal diameter, a broad nasal bridge, bilateral epicanthic folds and esotropia, broad palatine ridges with a central ridge, prominent ears, bilateral clinodactyly of the fifth fingers, and partial cutaneous syndactyly of the 3rd and 4th toes" [35]. The patient reported by Chaer et al. (2018) was diagnosed with great vessel transposition, two palmar creases in the right hand, bilateral syndactyly of the second and third toes, facial dysmorphism (unspecified by the authors), hemangiomas on the neck and the calf, and a left occipital plagiocephaly (chromosomal microarray gave normal result) [38].

Interestingly, in 2020, Pode-Shakked et al. presented data on facial analysis to verify the hypothesis of recognizable facial features in MLIV [39]. Using the DeepGestalt algorithm [40], 50 two-dimensional facial images of 10 MLIV patients were analyzed and compared to age/sex-matched unaffected controls (Group A, $n=98$ ) as well as to individuals affected with one of 100 dysmorphic syndromes, excluding ML-IV (Group B, $n=99$ ). Assessments were computed and classification results described by a distribution curve, the receiver operating characteristic (ROC) curve and its respective area under the curve (AUC). The authors noted that the ML-IV cohort showed a mean AUC of $0.822(p$-value $<0.01)$ when compared to Group A and an AUC of 0.885 ( $p$-value < 0.001) in comparison to Group B [40].

The facial phenotype of MLIV was nevertheless not specified by the authors. From our perspective and clinical experience with dysmorphic syndromes, the facial features typical for MLIV may consist of open-mouth appearance, a long face, which narrows with age, and puffy eyelids. Those, however, are not distinctive and overlap with characteristics of other genetic syndromes. Moreover, as clearly noted in Table 1, the features change with age, which makes a phenotypic diagnosis of MLIV very challenging. DeepGestalt technology seems thus to be beneficial for the elucidation and characterization of MLIV, as it has been already proved for other dysmorphic syndromes.

\subsection{Neurological Findings}

The clinical and neuroimaging findings suggest that the MCOLN1 gene has a critical role in central nervous system development and in preserving neuronal integrity in the retina and cerebellum.

From a neurological perspective, significant psychomotor development delay (observed in early infancy), with hypotonia, tendon hyperreflexia, and lack of language development, are common 
features. The development usually never progresses beyond the age of 1-2 years [41]. Receptive language is, however, better than expressive. Affected children rarely achieve walking ability, and only some can sit unsupported [35]. In our clinical practice, all adult cases affected with MLIV are able to walk although myopathy has become more prominent with age (Table 1). 
Table 1. Reports of mild or atypical manifestation of MLIV.

\begin{tabular}{|c|c|c|c|c|c|}
\hline Reference & $\begin{array}{l}\text { Case and Age at } \\
\text { Diagnosis }\end{array}$ & Gastrin Concentration & $\begin{array}{c}\text { Skin/Conjunctival Biopsy } \\
\text { Result }\end{array}$ & MCOLN1 Genotype a & Features \\
\hline Riedel et al. 1985 [37] & $\begin{array}{l}\text { 23-year-old male and his } \\
\text { brother }\end{array}$ & $\mathrm{N} / \mathrm{A}$ & $\begin{array}{l}\text { conjunctival biopsy: } \\
\text { membrane-bound vacuoles } \\
\text { filled with fibrillogranular } \\
\text { material and concentric } \\
\text { membranous lamellar bodies } \\
\text { indicating both storage } \\
\text { of mucopolysaccharides and } \\
\text { complex lipids }\end{array}$ & N/A & $\begin{array}{l}\text { no corneal opacities until teens age; facial } \\
\text { dysmorphism (described in the text) }\end{array}$ \\
\hline Amir et al. 1987 [34] & $\begin{array}{c}20 \text { Ashkenazic Jewish } \\
\text { patients }(10 \mathrm{~F} / 10 \mathrm{M}) \text { aged } \\
2-17 \text { years }\end{array}$ & N/A & $\begin{array}{l}\text { typical inclusion organelles on } \\
\text { electron microscopy of } \\
\text { conjunctival biopsy and/or skin } \\
\text { biopsy tissue. The diagnosis was } \\
\text { confirmed by demonstrating } \\
\text { abnormal gangliosides storage in } \\
\text { cultured fibroblasts. }\end{array}$ & N/A & $\begin{array}{l}\text { developmental delay, corneal clouding, } \\
\text { language function reduced }\end{array}$ \\
\hline Chitayat et al. 1991 [35] & $\begin{array}{l}5 \text { patients aged } 20 \text { months } \\
\text { to } 32 \text { years }\end{array}$ & $\mathrm{N} / \mathrm{A}$ & skin and conjunctival biopsies & N/A & $\begin{array}{l}\text { minor congenital anomalies and facial } \\
\text { dysmorphism ( } 1 \text { case, described in the } \\
\text { text); } \\
\text { puffy eyelids ( } 5 \text { cases), ptosis; } \\
\text { coarsening of the facial appearance; } \\
\text { myopathic face, a decline in facial } \\
\text { movement; } \\
\text { delayed onset puberty and no associated } \\
\text { growth spurt ( } 1 \text { case) }\end{array}$ \\
\hline Casteels et al. 1992 [42] & 16 years old girl & $\mathrm{N} / \mathrm{A}$ & conjunctival biopsy & $\mathrm{N} / \mathrm{A}$ & $\begin{array}{l}\text { ophthalmological findings as the only } \\
\text { features }\end{array}$ \\
\hline Reis et al. 1993 [43] & 16 years old girl & N/A & conjunctival biopsy & $\mathrm{N} / \mathrm{A}$ & $\begin{array}{l}\text { minor motor difficulties; mild } \\
\text { psychological disturbances }\end{array}$ \\
\hline
\end{tabular}


Table 1. Cont.

\begin{tabular}{|c|c|c|c|c|c|}
\hline Reference & $\begin{array}{l}\text { Case and Age at } \\
\text { Diagnosis }\end{array}$ & Gastrin Concentration & $\begin{array}{c}\text { Skin/Conjunctival Biopsy } \\
\text { Result }\end{array}$ & MCOLN1 Genotype a & Features \\
\hline \multirow{11}{*}{ Altarescu et al. 2002 [33] } & \multirow{11}{*}{$\begin{array}{c}28 \text { patients (age range } 2 \text { to } \\
25 \text { ), age at diagnosis } 1 \text { to } \\
14 \text { years }\end{array}$} & \multirow{11}{*}{$\begin{array}{c}1507 \\
\mathrm{pg} / \mathrm{mL} \\
\text { (range } 400 \text { to } 4100 \mathrm{pg} / \mathrm{mL}, \\
\text { normal } 0 \text { to } 200 \mathrm{pg} / \mathrm{mL} \text { ) }\end{array}$} & \multirow{11}{*}{$\begin{array}{l}\text { skin or conjunctival biopsies } \\
\text { and in cultured skin fibroblasts }\end{array}$} & $\begin{array}{c}\text { c. }[406-2 \mathrm{~A}>\mathrm{G}] ;[406-2 \mathrm{~A}>\mathrm{G}] \\
\text { p.?/p.? } \\
9 \text { pts }\end{array}$ & \multirow{11}{*}{$\begin{array}{l}\text { independent, ataxic, spasticity, reduced } \\
\text { tone } \\
\text { gait, modified pincer grasp (patient no } \\
\text { 15); } \\
\text { severe visual impairment as the only } \\
\text { feature (patient no 13) }\end{array}$} \\
\hline & & & & $\begin{array}{c}\text { c.[-1015_789del];[406-2A>G] } \\
\text { p.0/p.? } \\
\text { 8 pts }\end{array}$ & \\
\hline & & & & $\begin{array}{c}\text { c.[-1015_789del];[-1015_789del] } \\
\text { p.0/p.0 }\end{array}$ & \\
\hline & & & & $\begin{array}{c}\text { c. }[304 \mathrm{C}>\mathrm{T}] ;[1084 \mathrm{G}>\mathrm{T}] \\
\text { p.(Arg102*)/p.(Asp362Tyr) }\end{array}$ & \\
\hline & & & & $\begin{array}{c}\text { c.[406-2A>G];[1222_1224del] } \\
\text { p.?/p.(Phe408del) }\end{array}$ & \\
\hline & & & & $\begin{array}{c}\text { c. }[1406 \mathrm{~A}>\mathrm{G}] ;[1406 \mathrm{~A}>\mathrm{G}] \\
\text { p.?/p.? }\end{array}$ & \\
\hline & & & & $\begin{array}{l}\text { c.[-1015_789del];[473_474del] } \\
\text { p.0/p.(Thr158Lysfs*25) }\end{array}$ & \\
\hline & & & & $\begin{array}{l}\text { c.1406A }>\text { G]; }[514 C>T] \\
\text { p.?/p.(Arg172*) }\end{array}$ & \\
\hline & & & & $\begin{array}{l}\text { c.[1084G>T];[?] }{ }^{b} \\
\text { p.(Asp362Tyr)/p.0 }\end{array}$ & \\
\hline & & & & $\begin{array}{l}\text { c.[1453_1463dup];;1453_1463dup] } \\
\text { p.(Ser488Argfs*96)/p.(Ser488Argfs*96) }\end{array}$ & \\
\hline & & & & $\begin{array}{c}\text { c.[317T }>\text { C];[1340T }>C] \\
\text { p.(Leu106Pro)/p.(Leu447Pro) }\end{array}$ & \\
\hline Bindu et al. 2008 [36] & $\begin{array}{c}4 \text { cases; aged } 14(2), 16 \\
\text { and } 18 \text { years }\end{array}$ & $\mathrm{N} / \mathrm{A}$ & $\begin{array}{l}\text { electron microscopic studies of } \\
\text { biopsy specimens } \\
\text { from skin, conjunctiva, peripheral } \\
\text { nerve, muscle and liver }\end{array}$ & & $\begin{array}{l}\text { no corneal abnormalities in all, optic } \\
\text { atrophy in } 1 \text { patient; } \\
\text { slowly progressive spastic paraparesis } \\
\text { from the second decade of life ( } 3 \\
\text { patients) and early childhood } \\
\text { ( } 1 \text { patient); thin corpus callosum; } \\
\text { intellectual disability ( } 3 \text { out of } 4 \text { patients) } \\
\text { diagnosis of non-compressive } \\
\text { myelopathy ( } 1 \text { case) } \\
\text { (atypical presentation) }\end{array}$ \\
\hline Tuysuz et al. 2009 [44] & Turkish patient & $\begin{array}{l}\text { hypergastrinemia, iron } \\
\text { deficiency anemia, }\end{array}$ & N/A & $\begin{array}{c}\text { c. }[1367 \mathrm{C}>\mathrm{T}] ;[1367 \mathrm{C}>\mathrm{T}] \\
\text { p.(Ser456Leu)/p.(Ser456Leu) }\end{array}$ & $\begin{array}{l}\text { defects in the posterior limb of the } \\
\text { internal capsule by MRI, cerebellar } \\
\text { atrophy, micrognathia, and clinodactyly } \\
\text { of the fifth fingers; spastic tetraplegia }\end{array}$ \\
\hline
\end{tabular}


Table 1. Cont.

\begin{tabular}{|c|c|c|c|c|c|}
\hline Reference & $\begin{array}{l}\text { Case and Age at } \\
\text { Diagnosis }\end{array}$ & Gastrin Concentration & $\begin{array}{c}\text { Skin/Conjunctival Biopsy } \\
\text { Result }\end{array}$ & MCOLN1 Genotype a & Features \\
\hline Geer at al. 2010 [45] & $\begin{array}{c}\text { 4.5-year-old girl } \\
\text { non-Jewish } \\
\text { 11-year-old non-Jewish } \\
\text { girl }\end{array}$ & $\begin{array}{c}710 \mathrm{pg} / \mathrm{mL} \\
(0-99 \mathrm{pg} / \mathrm{mL}) \\
526 \mathrm{pg} / \mathrm{mL} \\
(0-99 \mathrm{pg} / \mathrm{mL})\end{array}$ & $\begin{array}{l}\text { skin biopsy: } \\
\text { vacuoles containing granular } \\
\text { material and lipids compatible } \\
\text { with a lysosomal storage disease. }\end{array}$ & $\begin{array}{c}\text { c.[236_237ins93];[694A>C] } \\
\text { p.0?/p.(Thr232Pro) }\end{array}$ & $\begin{array}{l}\text { developmental delay, hypotonia, } \\
\text { language delays } \\
\text { hypotonia, limb spasticity, severe } \\
\text { hypoplasia of the corpus callosum }\end{array}$ \\
\hline $\begin{array}{l}\text { Mirabelli- Badenier et al. } \\
\text { 2014 [46] }\end{array}$ & 5-year old Italian male & $\begin{array}{c}191.26 \mathrm{pmol} / \mathrm{L} \\
(11-54 \mathrm{pmol} / \mathrm{L})\end{array}$ & & $\begin{array}{c}\text { c.[395_397del;468_474dup]; } \\
\text { [395_397del;468_474dup] } \\
\text { p.?/p.? c }\end{array}$ & $\begin{array}{l}\text { postnatal growth deficiency, } \\
\text { non-progressive psychomotor delay and } \\
\text { spasticity at onset in infancy }\end{array}$ \\
\hline Chaer et al. 2018 [38] & $\begin{array}{l}\text { 4-month-old French } \\
\text { Canadian boy diagnosed } \\
\text { at } 2\end{array}$ & $\begin{array}{c}726 \mathrm{ng} / \mathrm{L} \\
(0-90 \mathrm{ng} / \mathrm{L})\end{array}$ & $\begin{array}{l}\text { electron microscopy of skin } \\
\text { biopsy: } \\
\text { secondary lysosomes } \\
\text { filled with concentric lamellar } \\
\text { structures in the cytoplasm } \\
\text { of eccrine duct cells and, to a } \\
\text { lower extent, of } \\
\text { endothelial cells }\end{array}$ & $\begin{array}{c}\text { c.[694A }>\text { C];[785T }>C] \\
\text { (p.Thr232Pro)/(p.Phe262Ser) }\end{array}$ & $\begin{array}{l}\text { congenital anomalies and facial } \\
\text { dysmorphism; } \\
\text { hypoplastic optic nerves and a delayed } \\
\text { P100 wave on visual evoked potentials. }\end{array}$ \\
\hline Case 1 & $\begin{array}{l}20 \text { years Pakistani old } \\
\text { female }\end{array}$ & $157 \mathrm{pmol} / \mathrm{L}(<40 \mathrm{pmol} / \mathrm{L})$ & N/A & $\begin{array}{c}\text { c.[1256G >C];[1256G>C] } \\
\text { p.(Arg419Pro)/p.(Arg419Pro) }\end{array}$ & $\begin{array}{l}\text { GI: deranged liver function tests (ALT } \\
\text { 123 U/L, ALP 1078 U/L), USS liver } \\
\text { normal, fibroscan TE of } 8 \text { to } 9 \text { EkPa; gall } \\
\text { bladder polyp; } \\
\text { Eye: corneal clouding, cataracts, optic } \\
\text { atrophy, retinal pigmentation; } \\
\text { MRI head: subtle high signal in the } \\
\text { periventricular deep white matter, the } \\
\text { globus pallidus and thalamus signal } \\
\text { slightly lower than in the rest of the basal } \\
\text { ganglia on T2 sequences, suggestive of a } \\
\text { relative increase in iron deposition; } \\
\text { Hearing: sensorineural hearing loss, } \\
\text { Other: severe learning disability, } \\
\text { microcephaly, premature ovarian failure; } \\
\text { recurrent periods of depression and } \\
\text { anorexia }\end{array}$ \\
\hline Case 2 & $\begin{array}{l}\text { 23-year-old Pakistani } \\
\text { female }\end{array}$ & $179 \mathrm{pmol} / \mathrm{L}(<40 \mathrm{pmol} / \mathrm{L})$ & N/A & $\begin{array}{c}\text { c..[1256G }>\text { C];[1256G }>C] \\
\text { p.(Arg419Pro)/p.(Arg419Pro) }\end{array}$ & $\begin{array}{l}\text { GI: iron deficiency anemia at } \\
\text { presentation; } \\
\text { Developmental delay, severe learning } \\
\text { disability; } \\
\text { Eye: corneal clouding, optic nerve } \\
\text { atrophy, retinitis pigmentosa, registered } \\
\text { blind; } \\
\text { MRI: small corpus callosum, but } \\
\text { pituitary gland was unremarkable; } \\
\text { Hearing: Sensorineural hearing loss } \\
\text { Lost the ability to speak at the age of } \\
\text { 8-10 year; } \\
\text { CK 1400 U/L: congenital myopathy; } \\
\text { premature ovarian insufficiency; } \\
\text { MRI leg: osteofibrous dysplasia and } \\
\text { adamantinoma }\end{array}$ \\
\hline
\end{tabular}


Table 1. Cont.

\begin{tabular}{|c|c|c|c|c|c|}
\hline Reference & $\begin{array}{l}\text { Case and Age at } \\
\text { Diagnosis }\end{array}$ & Gastrin Concentration & $\begin{array}{c}\text { Skin/Conjunctival Biopsy } \\
\text { Result }\end{array}$ & MCOLN1 Genotype a & Features \\
\hline Case 3 & 27-year-old Pakistani male & $198 \mathrm{pmol} / \mathrm{L}(<40 \mathrm{pmol} / \mathrm{L})$ & N/A & $\begin{array}{c}\text { c.[1256G >C];[1256G>C] } \\
\text { p.(Arg419Pro)/p.(Arg419Pro) }\end{array}$ & $\begin{array}{l}\text { GI: constipation, iron deficiency anemia; } \\
\text { Eye: corneal clouding, retinitis } \\
\text { pigmentosa, deterioration of his vision } \\
\text { since the age of } 5 \text {, nystagmus, exotropia, } \\
\text { anterior and posterior subcapsular } \\
\text { cataracts; } \\
\text { Hearing: sensorineural hearing loss; } \\
\text { Myopathy CK } 3100 \mathrm{U} / \mathrm{L} ; \\
\text { MRI: atrophic corpus callosum, } \\
\text { microcephaly, deep white matter T2 } \\
\text { signal abnormalities and hypointense } \\
\text { thalami; } \\
\text { Lost ability to communicate at the age of } \\
\text { 15; } \\
\text { Depression, gynecomastia }\end{array}$ \\
\hline
\end{tabular}


Epileptiform discharges consistent with cortical dysfunction have been described in $60 \%$ of individuals [35] but are rarely associated with convulsions [47]. It has been postulated that extensive white matter disease inhibits the dissemination of epileptiform discharges. The neurological course of the disease is not unique, and therefore it can be challenging to differentiate it from other neurodegenerative diseases. The clinical diagnosis of MLIV may be even more complicated in cases with mild neurological symptoms or additional, coexisting features such as deafness (see cases 1-3 in Table 1).

\subsection{Myopathy}

Progressive lower limb weakness and ataxia has been documented in some genotypes of MLIV [33]. Children described in this study were sitting or walking with support. Adult-onset myopathy has also been observed in our adult patients (see cases 1-3, Table 1).

Spasticity and hypotonia are common features in this group of patients. Tendon reflexes are symmetrical and brisk in them; with most having bilateral Babinski signs.

Hand usage was significantly impaired in 27 patients [33]. Four patients could finger-feed themselves with solid food, whereas pincer grasp was present in very few children. In general, repeated neurologic exam has shown a stable course of the disease in $70 \%$ of children. Those who presented with deteriorated motor function have been shown to develop cerebellar signs [33].

In addition, swallowing complaints reported by parents/caregivers ranged from mild to severe, with severity of complaints reported increasing for solid textures [35]. Coughing during and following meals was reported in $86 \%$ of patients. All subjects reported drooling of varying levels of severity.

The ptosis, myopathic face, gradual decline in facial movements, persistent hypersalivation, and difficulties in chewing are thought to be associated with cranial nerves palsy. Contrary to Chitayat et al. [35], Schell-Apacik et al. (2008) have reported that some MLIV patients (10\%) may have hearing impairment [48].

\subsection{Secondary Mitochondrial Dysfunction}

Autophagic flux and autophagosome-lysosome fusion are defective in many LSDs, including MLIV [49,50]. Autophagic stress may cause accrual of damage organelles, including mitochondria, making the cells more predisposed to pro-apoptotic signals [51].

Mucolipidosis type IV (MLIV) fibroblasts have been shown to accumulate fragmented mitochondria and exhibit increased sensitivity to apoptosis induced by $\mathrm{Ca}^{2+}$-mobilizing agonists [47,52], and thus it has been postulated that modulation of autophagy might be an effective treatment mechanism for emerging therapies [5]. This approach has been recommended for the therapy of other neurodegenerative disorders [53,54]; autophagy induction with rapamycin has been shown to reduce neuronal death in animal studies on Huntington's disease [55]. Strategies that enhance autophagy may be critical in the treatment development of LSD as well as utilizing therapies that maximize residual mitochondrial respiratory chain activities. However, since multiple cellular pathways are impaired in LSDs, therapeutic strategies to ameliorate oxidative stress, improve mitochondrial function, and enhance autophagy may prove beneficial in the treatment of these rare disorders.

Mucolipin-1 (ML-1) is part of an important feedback loop between mTOR and TFEB; both are connected by the mTORC1-mediated phosphorylation of ML-1 [56]. Phosphorylation of ML-1 [57] reduces its channel activity and leads to reduced activation of TFEB as a transcription factor [56].

ML-1 has been shown to play a role in iron homeostasis, and its deficiency therefore results in abnormal iron regulation observed in MLIV patients [18,58]. Specifically, TRPML1 is a non-selective cation channel and acts in $\mathrm{Fe}^{2+}$ trafficking in late endosomes and lysosomes. Disturbed iron homeostasis is likely to impair brain myelination and contribute to the hematological symptoms of MLIV patients [57]. Importantly, iron catalyzes the synthesis of reactive oxygen species (ROS), and it is suggested that this build-up of iron in ML-1-deficient cells is a possible explanation of neurodegeneration and 
mitochondrial degradation [59]. Furthermore, ML-1 activity regulating lysosomal zinc levels has been shown to cause zinc accumulation in lysosomes and in the brain tissue in ML-IV patients [60].

\subsection{Brain Neuroimaging}

Among 15 MLIV patients, the body of the corpus callosum was well structured, while the physiological increase of the genu or splenium was not present [61]. White matter abnormalities (the distribution of the hyperintensities included the periventricular, deep, and subcortical white matter in T2-weighted images, reduced signal intensity in the basal ganglia, and cerebellar atrophy, which is more prominent in older patients) have been described.

As a result, hypoplasia of the body of the corpus callosum with dysplasia/absence of the splenium and rostrum, and cerebellar atrophy have been described as pathognomonic neuroimaging characteristics of MLIV [44,56-64].

Increased T1-weighted signal and decreased T2-weighted sequences were consistent with ferritin deposition in the basal ganglia and thalami $[33,61,65,66]$.

A localized cerebral neurodegenerative process in MLIV has also been observed in five MLIV patients by Schiffmann et al. [66]. During a 3-year follow-up, the neurological function remained unchanged with enhanced cortical and subcortical grey matter volumes and ventricular size, and decreased white matter and cerebellar volumes. White matter involvement was illustrated by both incomplete myelination and additional focal periventricular areas of demyelination. Diffusion-weighted imaging have shown abnormal parameters in all patients and in all brain regions examined; hence, Schiffmann et al. [66] suggested diffusion-weighted imaging as an adequate and sensitive biomarker for long-term monitoring of MLIV patients [66].

The mechanism of developmental brain abnormalities and insufficient myelination and additional focal periventricular areas of demyelination is not clear [46,63,67]. It has been shown, however, in the Mcoln1(-/-) knockout mouse model of MLIV that glial cell activation was enhanced in the brain, while myelination in cerebral and cerebellar white matter tracts was reduced [68]. Pathogenesis and animal studies have been extensively described elsewhere [12].

However, it has been postulated that the defective protein in MLIV is essential to cells at different developmental stages of the corpus callosum [61]. Cerebral and cerebellar atrophy suggestive of progression of the disease has been prominent in older patients. Frei et al. [61] have concluded that these changes may not be present at birth, but appear at approximately 4 years of age and becomes evident in the second or third decade of life [61].

MR spectroscopic imaging showed greater changes in neurons in the cerebellum and white matter compared to the basal ganglia and parietal cortex [69]. In addition, an autopsy case report has shown a reduction in numbers of neurons and astrocytosis were found in the thalamus, hippocampus (CA3), substantia nigra, basis pontis, inferior olivary nucleus, spinal cord ventral horn, and cerebellar Purkinje cell layer [42,67].

While only $15 \%$ of patients show a remarkable neurological symptom progression retinal dystrophy rapidly progresses [35], hypotonia, hyperreflexia, spasticity and dystonia can be apparent during the slow progression of this disorder [35]. Apart from the severe form of MLIV presenting in infancy, atypical forms with milder phenotypes with non-progressive neurologic deficits and minimal ophthalmic abnormalities and no significant neurological dysfunction, as well as additional features, have also been reported in MLIV [35-38,43,45,68,69] (Table 1). They often lead to late diagnosis [41,70].

\subsection{Sleep Disturbance}

Patients who were able to reach stage two sleep, had sleep spindles and vertex waves, which were not concurrent in time [71] and which implied a defect in myelination of the corpus callosum and thalamocortical projections in the white matter in the cortex $[42,67,72]$. 


\subsection{Ocular Findings}

As no striking recognizable facial dysmorphism, skeletal anomalies, organomegaly, or lysosomal enzyme abnormalities in serum are common features of MLIV, the clinical diagnosis may, however, be significantly improved because of characteristic ophthalmological anomalies.

Most 5-year-old, and older patients had a reduced visual ability [41], and the cause was multifactorial. Amir et al. (1987) analyzed ophthalmologic features among 20 MLIV individuals and concluded that visual deterioration is likely to be associated with retinal degeneration rather than with corneal clouding [34].

The corneal opacities resulting from the accumulation of phospholipids, mucopolysaccharides, and gangliosides in the epithelial cells [27] have been shown to be apparent between infancy and 5 years of age, and its presence at birth is rare [34]. As corneal clouding is the first noticeable sign, it is often an important diagnostic clue in MLIV [34,35]. While corneal clouding may be present at birth and progress over time, other clinical features may not be recognized for several years. Apart from corneal clouding, strabismus is most often the first sign [17] in 63\% of children and became evident before 3 months of age in five children, 3 to 6 months in eight children, and 7 to 12 months in four children [17].

Affected individuals usually have corneal clouding or opacities of varying degrees but bilateral and symmetric gradual fibrous dysplasia and retinal degeneration with severe visual impairment have also been demonstrated by their early teens [37]. The remaining ophthalmic features include optic atrophy, cataract, ptosis, and ocular pain from corneal abrasion [17,34], esotropia, severe myopia, eye lid swelling, epiphora and ipsilateral facial flushing, conjunctival injection, photophobia, early cataract formation, and retinal vascular attenuation $[34,35,37,73]$. Abnormal eye movements, such as nystagmus or roving eye movements, have been documented in $23 \%$ of patients. whereas strabismus has been found in $54.5 \%$ of patients, with esotropia in seven, exotropia in four, and right gaze preference [17] in one patient. In single reports, MLIV manifested as isolated retinal dystrophy [74,75].

Chaer et al. (2018) demonstrated the first spectral domain optical coherence tomography (SD-OCT) imaging of abnormal corneal epithelium in a 2-year-old patient affected with MLIV [38]. The proband underwent ophthalmologic evaluation of possible eye movements because of prenatally diagnosed transposition of the great vessels and suspicion of vermis hypoplasia. It revealed pale optic nerves, arteriolar attenuation, and retinal pigmentary changes; hypoplastic optic nerves and a delayed P100 wave on visual evoked potentials (VEP) were noted. The corneal epithelium was hyperreflective, measured at $13.4 \mathrm{~mm}$ (normal, 3-4 mm), while the total central corneal thickness was $579 \mathrm{~mm}$ [38].

The electroretinogram (ERG) and visual-evoked potentials in the MLIV child have been shown to be normal [74]. In a different study, ERG gave evidence of the electronegative responses to a scotopic bright flash, which may suggest a disturbance in the inner segments of the photoreceptors, bipolar cells, or other middle retinal neurons [76].

\subsection{Achlorydia}

Achlorhydria and hypergastrinemia are hallmark findings of MLIV [12,18]. All MLIV patients have been documented to suffer from achlorhydria associated with secondary increases in blood gastrin at $1507 \mathrm{pg} / \mathrm{mL}$ (range 400 to $4100 \mathrm{pg} / \mathrm{mL}$; normal 0 to $200 \mathrm{pg} / \mathrm{mL}$ ) [33] (Table 1).

Achlorydia and frequent malabsorption of iron from food results in iron deficiency in MLIV patients $[18,33,41,60,64,77]$. Distended parietal cells containing large vacuoles with lamellar, concentric inclusions were identified on gastroscopy $[17,18]$. Elevated gastrin and cellular vacuolization have been confirmed in the Mcoln1-/- mice [13], which have been remarkably similar to those of MLIV patients [18].

The universal achlorhydria in patients with MLIV indicates that fully functional mucolipin is necessary for normal hydrochloric acid secretion [33]. Iron deficiency could be attributed to the alteration of $\mathrm{Fe}^{3+}$ absorption secondary to achlorhydria. 
All MLIV patients had hypergastrinemia and showed chronic atrophic gastritis and enterochromaffinlike (ECL) cell hyperplasia on histologic evaluation of the stomach [77,78]. Atrophic changes, gastritis, and ECL cell hyperplasia have been observed even in the youngest patient. The severity of the inflammation in mucosae, chronic gastritis, and chronic atrophy identified on biopsies increased with age and were secondary to longstanding achlorhydria [78,79].

Frequent diarrhea has been documented in $38 \%$ and constipation in $5 \%$ of patients [34].

\subsection{Skin}

Definitive diagnosis of MLIV requires (unless by genetic testing) electron microscopic evaluation of cultured skin fibroblasts or a biopsy specimen obtained from the skin fibroblasts, corneal and conjunctival epithelial cells, conjunctival goblet cells, corneal keratocytes or in the cytoplasm of eccrine duct cells, and, to a lesser extent, of endothelial cells, skeletal muscle, and cerebral white matter $[38,42,79,80]$. Cultured skin fibroblasts from MLIV patients have been demonstrated to be autofluorescent [81].

Histopathologic findings consist of single-membrane limited cytoplasmic vacuoles containing both fibrillogranular material and membranous lamellae and concentric bodies forming concentric whorls $[35,36,47,82,83]$. Membrane-bound vacuoles have been shown to be present in endothelial cells, fibroblasts, and glandular epithelial cells, and membrane cytoplasmic bodies in glandular epithelial and in endothelial cells $[84,85]$.

These intracellular amorphous materials represent moderate storage of mucopolysaccharides, phospholipids, and gangliosides [86], which explains heterogeneity in the material discovered within the lysosomes. Bach et al. (2005) have demonstrated that these macromolecules are transported into lysosomes at an increased rate, and not into the Golgi bodies to be recycled into new cell membrane [30]. Normal catabolism of these macromolecules is a possible explanation of the mild clinical features and organomegaly but the presence of slow neurodevelopmental deterioration [35].

In the cornea, the keratocytes epithelium is affected, whereas the endothelium, Bowman's layer, and Descemet's membrane have been shown to be spared [80].

\subsection{Other Laboratory and Significant Clinical Findings}

Altarescu et al. (2002) have observed that $46 \%$ of MLIV patients had iron deficiency, and $36 \%$ of them were anemic [33].

It has been shown that many adult patients (in their $20 \mathrm{~s}$ and $30 \mathrm{~s}$ ) manifest renal disease or failure [5]. Thus, there is still a need to monitor and report MLIV individuals, especially older ones, to confirm our understanding of the life-long course of this disorder.

\section{Discussion}

The nonspecific or, rarely, isolated (i.e., the involvement of the epithelium seen on SD-OCT or hypergastrinemia) initial clinical and biochemical findings in MLIV and the lack of a non-invasive, specific diagnostic test (i.e., enzymology testing), most likely lead to misdiagnosis or delayed diagnosis of MLIV. In the recent past, the diagnosis was made by skin or conjunctival biopsy. Currently, access to genetic mutation analysis, including next-generation sequencing (NGS), allows the identification of mutations in the MCOLN1 gene, confirming the clinical suspicion as well as genotypic correlation of the clinical features (Table 2). 
Table 2. Diagnostic pathway of MLIV.

\begin{tabular}{|c|c|}
\hline Pathway & Diagnostic Clues \\
\hline $\begin{array}{c}\text { primary clinical } \\
\text { manifestations, } \\
\text { sequence of symptoms }\end{array}$ & $\begin{array}{l}\text { - In the first year of life, bilateral corneal clouding and strabismus may be the first signs noted, prompting referral to the pediatric } \\
\text { ophthalmologist and geneticist; } \\
\text { - } \quad \text { Ny the age of } 2 \text { years, developmental delay and corneal clouding are evident (regression is not a characteristic); } \\
\text { children older than } 4 \text { years), peculiar basal ganglia signal anomalies, marked corpus callosum hypoplasia, and white matter } \\
\text { abnormalities played a crucial role in the differential diagnosis [46]; } \\
\text { - Feeding difficulties with growth failure are typical, described in patients from childhood to adulthood; of note: various degrees of } \\
\text { developmental and motor delay are observed, but the neurologic status is stable; } \\
\text { - In early childhood, hypergastrinemia is noted; of note: gastrin level assessment may be of high diagnostic value, as a cost-effective } \\
\text { evaluation of every child with global unexplained developmental delay (especially those who are hypotonic, non-ambulatory, } \\
\text { - } \quad \text { Hypotonia, pyramidal tract signs, spastic quadriplegia, and severe dysarthria are among vital neurologic abnormalities; } \\
\text { - } \quad \text { Dystrophic retinopathy, if it occurs, may be progressive; } \\
\text { - In approximately } 50 \% \text { of patients, iron deficiency occurs [17]; } \\
\text { - In adults, myopathy, spasticity, and impaired hand usage are observed; } \\
\text { From the second/third decade, renal failure may be observed }\end{array}$ \\
\hline diagnostic work-up & $\begin{array}{l}\text { - Suspicion based on clinical diagnosis (neurologic and/or ocular symptoms and brain neuroimaging) should be verified in skin or } \\
\text { - } \quad \text { Gastrinctival biopsy to find characteristic lamellar and polymorphous cytoplasmic inclusions in the cells; } \\
\text { - } \quad \text { Genetic testing to identify pathogenic variants in MCOLIN1; } \\
\text { - } \quad \text { Muscle biopsy (no value for MLIV recognition/confirmatory, only as differential diagnosis procedure) }\end{array}$ \\
\hline $\begin{array}{l}\text { molecular testing } \\
\text { and family counselling }\end{array}$ & $\begin{array}{l}\text { - In Ashkenazi Jews two variants of MCOLN1 (c.406-2A>G or c.-1015_789del) account for 95\% cases; } \\
\text { - In total, } 35 \text { MCOLN1 variants are known in MLIV patients; } \\
\text { - } \quad \text { No genotype-correlation was documented; } \\
\text { - } \quad \text { Intrafamilial clinical heterogenicity should be considered in genetic counselling; } \\
\text { For at-risk families, with known genotypes, prenatal or preimplantation genetic testing (PGT) can be offered }\end{array}$ \\
\hline
\end{tabular}


Table 2. Cont

\begin{tabular}{cll}
\hline Pathway & - $\begin{array}{l}\text { The clinical need for patients' registry as crucial instruments to develop clinical research, to improve patient care and healthcare } \\
\text { planning, to facilitate the planning of appropriate clinical trials, and to assess the feasibility of clinical trials }\end{array}$ \\
\hline follow-up & Currently, no cure or corrective management exist; therapy is symptomatic; of note: penetrating corneal graft surgery is ineffective; \\
\hline treatment & $\begin{array}{l}\text { Modulation of autophagy (activation, with caloric restriction or treatment with rapamycin) might be an effective strategy for } \\
\text { treatment [5,54]; }\end{array}$ \\
\hline & $\begin{array}{l}\text { Small molecule therapy using miglustat was shown to delay the cerebellar disease in the MLIV mouse model (but has not yet been } \\
\text { tested in humans) [5] }\end{array}$ \\
\hline
\end{tabular}


Molecular analysis is the most effective diagnostic test, because it allows determination of the cause of the disease in $99 \%$ of affected individuals, regardless of age, disease severity, and phenotypic spectrum. Genetic testing for the two most common mutations is indicated, particularly in patients of Jewish ethnicity (allows for diagnosis in 95\% of patients), but can commonly be negative in non-Jewish individuals. It is recommended that sequence analysis of MCOLN1 is performed first, followed by gene-targeted deletion/duplication analysis in individuals with only one or no pathogenic variants. The NGS gene panel, which includes the MCOLN1 gene, whole exome, or genome analysis, may also be considered, especially for patients with a high index of clinical suspicion of MLIV or an atypical clinical phenotype of this condition. The latter two methods allow for identification of both single nucleotide polymorphism (SNP) and copy number variants (indels, CNV), also in non-coding regions of the genes.

Regarding the genotype-phenotype correlation, it was proposed based on the location of the variants within the MCOLN1 gene [41]. As reviewed in Supplementary Materials Table S1, variants in the loop between the first and second transmembrane domain resulted in a mild phenotype; severe presentation was, however, also observed (c.694A $>$ C). In patients with variants in the third transmembrane domain, mild neurological manifestation with progressive retinal diseases was noted. The mildest MLIV phenotype results from variants in the fourth transmembrane domain, while mutations located between the fifth and sixth transmembrane domain were identified in patients with severe manifestation. Considering our adult patients (Table 1 and Supplementary Materials Table S1), they present severe phenotype of MLIV and, therefore, fall into the last category of variants. The causative variants $($ c.1256G $>$ C) were localized in exon 11, TM4-TM5 loop, which were not previously described. Thus, we gave novel insight into the genotype-phenotype correlations in MCOLN1-related disease.

The sequence of symptom progression may vary in MLIV patients with developmental delay and deterioration in their vision in childhood, followed by deterioration in their speech and muscle function in early teens. Persistent iron deficiency anemia and constipation have been common complications in our adult patients. Sensorineural hearing loss, although not described before, was part of the clinical sequelae among all three adult patients.

\section{Conclusions}

The diagnosis of MLIV in children and adults proves to be challenging. The knowledge of classical and atypical presentations of MLIV helps correlate phenotype and genotype and assists in establishing the correct diagnosis. Currently, serum gastrin concentration and brain MRI play a vital role in the diagnostic pathway. A comprehensive molecular analysis of the MCOLN1 gene is key to achieving the definitive diagnosis of MLIV and giving reliable genetic counselling to families at risk. Furthermore, advanced imaging methods, such as diffusion-tensor imaging, may play a role as "functional biomarkers" in the long-term follow-up of these patients. Currently, apart from supportive management, no therapy is available for this rare condition.

Supplementary Materials: The following are available online at http://www.mdpi.com/1422-0067/21/12/4564/s1, Table S1. Detailed data of MCOLN1 molecular variants used in Table 1.

Author Contributions: A.J.-S., E.C., and K.M.S. were involved in designing the concept of the review and oversight, and contributed to the literature review and description of all the cases. A.J.-S. and K.M.S. drafted the manuscript. E.C. contributed to the analysis and interpretation of the genetic mutations. All authors contributed to the overall writing and reviewing of the manuscript. All authors have read and agreed to the published version of the manuscript.

Funding: This research received no external funding.

Conflicts of Interest: All authors have no conflict of interest for this publication.

Ethical Issues: Consent was obtained from three cases included. 


\section{References}

1. Bargal, R.; Avidan, N.; Ben-Asher, E.; Olender, Z.; Zeigler, M.; Frumkin, A.; Raas-Rothschild, A.; Glusman, G.; Lancet, D.; Bach, G. Identification of the gene causing mucolipidosis type IV. Nat. Genet. 2000, 26, 118-123. [CrossRef]

2. Bassi, M.T.; Manzoni, M.; Monti, E.; Pizzo, M.T.; Ballabio, A.; Borsani, G. Cloning of the gene encoding a novel integral membrane protein, mucolipidin-and identification of the two major founder mutations causing mucolipidosis type IV. Am. J. Hum. Genet. 2000, 67, 1110-1120. [CrossRef]

3. Cantiello,H.F.; Montalbetti, N.; Goldmann, W.H.; Raychowdhury, M.K.; Gonzalez-Perrett, S.; Timpanaro, G.A.; Chasan, B. Cation channel activity ofmucolipin-1: The effect of calcium. Pflugers Arch. 2005, 451, 304-312. [CrossRef]

4. Laplante, J.M.; Sun, M.; Falardeau, J.; Dai, D.; Brown, E.M.; Slaugenhaupt, S.A.; Vassilev, P.M. Lysosomal exocytosis is impaired in mucolipidosis type IV. Mol. Genet. Metab 2006, 89, 339-348. [CrossRef]

5. Boudewyn, L.; Walkley, S.U. Current concepts in the neuropathogenesis of Mucolipidosis type IV. J. Neurochem. 2019, 148, 669-689. [CrossRef]

6. Cuajungco, M.P.; Silva, J.; Habibi, A.; Valadez, J.A. The mucolipin-2 (TRPML2) ion channel: A tissue-specific protein crucial to normal cell function. Pflugers Arch. 2016, 468, 177-192. [CrossRef] [PubMed]

7. Sun, M.; Goldin, E.; Stahl, S.; Falardeau, J.L.; Kennedy, J.C.; Acierno, J.S., Jr.; Bove, C.; Kaneski, C.R.; Nagle, J.; Bromley, M.C.; et al. Mucolipidosis type IV is caused by mutations in a gene encoding a novel transient receptor potential channel. Hum. Mol. Genet. 2000, 9, 2471-2478. [CrossRef] [PubMed]

8. Bach, G. Mucolipidosis type IV. Mol. Genet. Metab. 2001, 73, 197-203. [CrossRef]

9. Chen, C.S.; Bach, G.; Pagano, R.E. Abnormal transport along the lysosomal pathway in mucolipidosis, type IV disease. Proc. Natl. Acad. Sci. USA 1998, 95, 6373-6378. [CrossRef] [PubMed]

10. Vergarajauregui, S.; Puertollano, R. Two di-leucine motifs regulate trafficking of mucolipin-1 to lysosomes. Traffic 2006, 7, 337-353. [CrossRef]

11. Miller, A.; Schafer, J.; Upchurch, C.; Sponer, E.; Huynh, J.; Hernandez, S.; McLaucghlin, B.; Oden, L.; Fares, H. Mucolipidosis Type IV protein TRPML1-dependent lysosome formation. Traffic 2015, 16, 284-297. [CrossRef] [PubMed]

12. Wakabayashi, K.; Gustafson, A.M.; Sidransky, E.; Goldin, E. Mucolipidosis type IV: An update. Mol. Genet. Metab. 2011, 104, 206-213. [CrossRef] [PubMed]

13. Venugopal, B.; Browning, M.F.; Curcio-Morelli, C.; Varro, A.; Michaud, N.; Nanthakumar, N.; Walkley, S.U.; Pickel, J.; Slaugenhaupt, S.A. Neurologic, gastric and ophthalmologic pathologies in a murine model of Mucolipidosis type IV. Am. J. Hum. Genet. 2007, 81, 1070-1083. [CrossRef] [PubMed]

14. Lemons, R.M.; Thoene, J.G. Mediated calcium transport by isolated human fibroblast lysosomes. J. Biol. Chem. 1991, 266, 14378-14382. [PubMed]

15. LaPlante, J.M.; Falardeau, J.; Sun, M.; Kanazirska, M.; Brown, E.M.; Slaugenhaupt, S.A.; Vassilev, P.M. Identification and characterization of the single channel function of human mucolipin-1 implicated in mucolipidosis type IV, a disorder affecting the lysosomal pathway. FEBS Lett. 2002, 532, 183-187. [CrossRef]

16. Reddy, A.; Caler, E.V.; Andrews, N.W. Plasma membrane repair is mediated by $\mathrm{Ca}(2+)$-regulated exocytosis of lysosomes. Cell 2001, 106, 157-169. [CrossRef]

17. Smith, J.; Chi-Chao, C.; Goldin, E.; Schiffmann, R. Noninvasive diagnosis and ophthalmic features of Mucolipidosis type IV. Ophthalmology 2002, 109, 588-594. [CrossRef]

18. Schiffmann, R.; Dwyer, N.K.; Lubensky, I.A.; Tsokos, M.; Sutliff, V.E.; Latimer, J.S.; Frei, K.P.; Brady, R.O.; Barton, N.W.; Blanchette-Mackie, E.J.; et al. Constitutive achlorhydria in mucolipidosis type IV. Proc. Natl Acad. Sci. USA 1998, 95, 1207-1212. [CrossRef]

19. Minke, B. The history of the Drosophila TRP channel: The birth of a new channel superfamily. J. Neurogenet. 2010, 24, 216-233. [CrossRef]

20. Puertollano, R.; Kiselyov, K. TRPMLs: In sickness and in health. Am. J. Physiol. Ren. Physiol. 2009, 296, F1245-F1254. [CrossRef]

21. Cheng, X.; Shen, D.; Samie, M.; Xu, X. Mucolipins: Intracellular TRPML1-3 Channels. FEBS Lett. 2010, 584, 2013-2021. [CrossRef] [PubMed]

22. Abe, K.; Puertollano, R. Role of TRP channels in the regulation of the endosomal pathway. Physiology 2011, 26, 14-22. [CrossRef] [PubMed] 
23. Kim, H.J.; Soyombo, A.A.; Tjon-Kon-Sang, S.; So, I.; Muallem, S. The Ca(2+) channel TRPML3 regulates membrane trafficking and autophagy. Traffic 2009, 10, 1157-1167. [CrossRef] [PubMed]

24. Martina, J.A.; Lelouvier, B.; Puertollano, R. The calcium channel mucolipin-3 is a novel regulator of trafficking along the endosomal pathway. Traffic 2009, 10, 1143-1156. [CrossRef] [PubMed]

25. Vergarajauregui, S.; Connelly, P.S.; Daniels, M.P.; Puertollano, R. Autophagic dysfunction in Mucolipidosis type IV patients. Hum. Mol. Genet. 2008, 17, 2723-2737. [CrossRef]

26. Park, S.; Ahuja, M.; Kim, M.S.; Brailoiu, G.C.; Jha, A.; Zeng, M.; Baydyuk, M.; Wu, L.G.; Wassif, C.A.; Porter, F.D.; et al. Fusion of lysosomes with secretory organelles leads to uncontrolled exocytosis in the lysosomal storage disease mucolipidosis type IV. EMBO Rep. 2016, 17, 266-278. [CrossRef]

27. Berman, E.R.; Livni, N.; Shapira, E.; Merin, S.; Levij, I.S. Congenital corneal clouding with abnormal systemic storage bodies: A new variant of mucolipidosis. J. Pediatr. 1974, 84, 519-526. [CrossRef]

28. Hantash, F.M.; Olson, S.C.; Anderson, B.; Buller, A.; Chen, R.; Crossly, B.; Sun, W.; Strom, C.M. Rapid one-step carrier detection assay of mucolipidosis IV mutations in the Ashkenazi Jewish population. J. Mol. Diagn. 2006, 8, 282-287. [CrossRef]

29. HGMD Professional. Available online: http://www.hgmd.cf.ac.uk/ac/index.php (accessed on 31 May 2020).

30. Bach, G. Mucolipin 1: Endocytosis and cation channel: A review. Eur. J. Physiol. 2005, 451, $313-317$. [CrossRef]

31. Wang, Z.H.; Zeng, B.; Pastores, G.M.; Raksadawan, N.; Ong, E.; Kolodny, E.H. Rapid detection of the two common mutations in Ashkenazi Jewish patients with mucolipidosis type. Genet. Test. 2001, 5, 87-92. [CrossRef]

32. Goldin, E.; Stahl, S.; Cooney, A.M.; Kaneski, C.R.; Gupta, S.; Brady, R.O.; Ellis, J.R.; Schiffmann, R. Transfer of a mitochondrial DNA fragment to MCOLN1 causes an inherited case of mucolipidosis IV. Hum. Mutat. 2004, 24, 460-465. [CrossRef] [PubMed]

33. Altarescu, G.; Sun, M.; Moore, D.F.; Smith, J.A.; Wiggs, E.A.; Solomon, B.I.; Patronas, N.J.; Frei, K.P.; Gupta, S.; Kaneski, C.R.; et al. The neurogenetics of mucolipidosis type IV. Neurology. 2002, 59, 306-313. [CrossRef] [PubMed]

34. Amir, N.; Zlotogora, J.; Bach, G. Mucolipidosis type IV: Clinical spectrum and natural history. Pediatrics 1987, 79, 953-959. [PubMed]

35. Chitayat, D.; Meunier, C.M.; Hodgkinson, K.A.; Silver, K.; Flanders, M.; Anderson, I.J.; Little, J.M.; Whiteman, D.A.H.; Carpenter, S. Mucolipidosis type IV: Clinical manifestations and natural history. Am. J. Med. Genet. 1991, 41, 313-318. [CrossRef]

36. Bindu, P.S.; Gayathri, N.; Yasha, T.C.; Kovoor, J.M.E.; Subasree, R.; Rao, S.; Panda, S.; Kumar, P. A Variant Form of Mucolipidosis IV: Report on 4 Patients From the Indian Subcontinent. J. Child. Neurol. 2008, 23, 1443-1446. [CrossRef]

37. Riedel, K.; Zwaan, J.; Kenyon, K.; Kolodny, E.; Hänninen, L.; Albert, D. Ocular abnormalities in mucolipidosis IV. Am. J. Ophthalmol. 1985, 99, 125-136. [CrossRef]

38. Chaer, L.; Harissi-Dagher, M.; Soucy, J.F.; Ellezam, B.; Hamel, P. Mucolipidosis type IV in a child. J. AAPOS 2018, 22, 469-471. [CrossRef]

39. Pode-Shakked, B.; Finezilber, Y.; Levi, Y.; Putter, S.; Fleischer, N.; Greenbaum, L.; Raas-Rothschild, A. Shared facial phenotype of patients with mucolipidosis type IV: A clinical observation reaffirmed by next generation phenotyping. Eur. J. Med. Genet. 2020, 103927. [CrossRef]

40. Gurovich, Y.; Hanani, Y.; Bar, O.; Nadav, G.; Fleischer, N.; Gelbman, D.; Basel-Salmon, L.; Krawitz, P.M.; Kamphausen, S.B.; Zenker, M.; et al. Identifying facial phenotypes of genetic disorders using deep learning. Nat. Med. 2019, 25, 60-64. [CrossRef]

41. Schiffmann, R.; Grishchuk, Y.; Goldin, E. Mucolipidosis IV. In GeneReviews ${ }^{\circledR}$; Adam, M.P., Ardinger, H.H., Pagon, R.A., Wallace, S.E., Eds.; University of Washington: Seattle, WA, USA, 1993.

42. Folkerth, R.D.; Alroy, J.; Lomakina, I.; Skutelsky, E.; Raghavan, S.S.; Kolodny, E.H. Mucolipidosis IV: Morphology and histochemistry of an autopsy case. J. Neuropathol. Exp. Neurol. 1995, 54, 154-164. [CrossRef]

43. Casteels, I.; Taylor, D.S.; Lake, B.D.; Spalton, D.J.; Bach, G. Mucolipidosis type IV. Presentation of a mild variant. Ophthalmic Paediatr. Genet. 1992, 13, 205-210. [CrossRef]

44. Sener, R.N. Chiari I malformation associated with callosal dysgenesis and ectopic neurohypophysis. Comput. Med. Imaging Graph. 1995, 19, 487-489. [CrossRef] 
45. Reis, S.; Sheffer, R.N.; Merin, S.; Luder, A.S.; Bach, G. Mucolipidosis type IV: A mild form with late onset. Am. J. Med. Genet. 1993, 47, 392-394. [CrossRef] [PubMed]

46. Di Rocco, M.; Rossi, A.; Parenti, G.; Allegri, A.E.; Filocamo, M.; Pessagno, A.; Tortori-Donati, P.; Minetti, C.; Biancheri, R. Different molecular mechanisms leading to white matter hypomyelination in infantile onset lysosomal disorders. Neuropediatrics 2005, 36, 265-269. [CrossRef]

47. Crandall, B.F.; Philippart, M.; Brown, W.J.; Bluestone, D.A. Review article: Mucolipidosis IV. Am. J. Med. Genet. 1982, 12, 301-308. [CrossRef] [PubMed]

48. Schell-Apacik, C.C.; Wagner, K.; Bihler, M.; Ertl-Wagner, B.; Heinrich, U.; Klopocki, E.; Kalscheuer, V.M.; Muenke, M.; von Voss, H. Agenesis and dysgenesis of the corpus callosum: Clinical, genetic and neuroimaging findings in a series of 41 patients. Am. J. Med. Genet. A 2008, 146, 2501-2511. [CrossRef] [PubMed]

49. Ward, C.; Martinez-Lopez, N.; Otten, E.G.; Carroll, B.; Maetzel, D.; Singh, R.; Sarkar, S.; Korolchuk, V.I. Autophagy, lipophagy and lysosomal lipid storage disorders. Biochim. Biophys. Acta 2016, 1861, 269-284. [CrossRef] [PubMed]

50. Grimm, C.; Butz, E.; Chen, C.C.; Wahl-Schott, C.; Biel, M. From Mucolipidosis type IV to Ebola: TRPML and two-pore channels at the crossroads of endo-lysosomal trafficking and disease. Cell Calcium 2017, 67, 148-155. [CrossRef]

51. Maiuri, M.C.; Zalckvar, E.; Kimchi, A.; Kroemer, G. Self-eating and self-killing: Crosstalk between autophagy and apoptosis. Nat. Rev. Mol. Cell Biol. 2007, 8, 741-752. [CrossRef]

52. Jennings, J.J.; Zhu, J.-H.; Rbaibi, Y.; Luo, X.; Chu, C.T.; Kiselyov, K. Mitochondrial aberrations in mucolipidosis Type IV. J. Biol. Chem. 2006, 281, 39041-39050. [CrossRef]

53. Bergamini, E.; Cavallini, G.; Donati, A.; Gori, Z. The role of macroautophagy in the ageing process, anti-ageing intervention and age-associated diseases. Int. J. Biochem. Cell Biol. 2004, 36, 2392-2404. [CrossRef] [PubMed]

54. Ingram, D.K.; Zhu, M.; Mamczarz, J.; Zou, S.; Lane, M.A.; Roth, G.S.; de Cabo, R. Calorie restriction mimetics: An emerging research field. Aging Cell 2006, 5, 97-108. [CrossRef] [PubMed]

55. Ravikumar, B.; Vacher, C.; Berger, Z.; Davies, J.E.; Luo, S.; Oroz, L.G.; Scaravilli, F.; Easton, D.F.; Duden, R.; $\mathrm{O}^{\prime}$ Kane, C.J.; et al. Inhibition of mTOR induces autophagy and reduces toxicity of polyglutamine expansions in fly and mouse models of Huntington disease. Nat. Genet. 2004, 36, 585-595. [CrossRef] [PubMed]

56. Onyenwoke, R.U.; Sexton, J.Z.; Yan, F.; Díaz, M.C.; Forsberg, L.J.; Major, M.B.; Brenman, J.E. The mucolipidosis IV Ca2+ channel TRPML1 (MCOLN1) is regulated by the TOR kinase. Biochem. J. 2015, 470, 331-342. [CrossRef] [PubMed]

57. Vergarajauregui, S.; Oberdick, R.; Kiselyov, K.; Puertollano, R. Mucolipin 1 channel activity is regulated by protein kinase A-mediated phosphorylation. Biochem. J. 2008, 410, 417-425. [CrossRef]

58. Grishchuk, Y.; Peña, K.A.; Coblentz, J.; King, V.E.; Humphrey, D.M.; Wang, S.L.; Kiselyov, K.I.; Slaugenhaupt, S.A. Impaired myelination and reduced brain ferric iron in the mouse model of mucolipidosis IV. Dis Model. Mech. 2015, 12, 1591-1601. [CrossRef]

59. Coblentz, J.; St. Croix, C.; Kiselyov, K. Loss of TRPML1 promotes production of reactive oxygen species: Is oxidative damage a factor in mucolipidosis type IV? Biochem. J. 2013, 457, 361-368. [CrossRef]

60. Cuajungco, M.P.; Basilio, L.C.; Silva, J.; Hart, T.; Tringali, J.; Chen, C.C.; Biel, M.; Grimm, C. Cellular zinc levels are modulated by TRPML1-TMEM163 interaction. Traffic 2014, 15, 1247-1265. [CrossRef]

61. Frei, K.P.; Patronas, N.J.; Cruchfield, K.E.; Altarescu, G.; Schiffmann, R. Mucolipidosis type IV: Characteristic MRI findings. Neurology 1998, 51, 565-569. [CrossRef]

62. Rakic, P.; Yakovlev, P.I. Development of the corpus callosum and cavum septi in man. J. Comp. Neurol. 1968, 132, 45-72. [CrossRef]

63. Barkovich, A.J.; Norman, D. Anomalies of the corpus callosum: Correlation with further anomalies of the brain. AJR Am. J. Roentgenol. 1988, 151, 171-179. [CrossRef] [PubMed]

64. Tüysüz, B.; Goldin, E.; Metin, B.; Korkmaz, B.; Yalçinkaya, C. Mucolipidosis type IV in a Turkish boy associated with a novel MCOLN1 mutation. Brain Dev. 2009, 31, 702-705. [CrossRef] [PubMed]

65. Gelman, B.B. Iron in CNS disease. J. Neuropathol Exp. Neurol 1995, 54, 477-486. [CrossRef] [PubMed]

66. Schiffmann, R.; Mayfield, J.; Swift, C.; Nestrasil, I. Quantitative neuroimaging in Mucolipidosis type IV. Mol. Genet. Metab. 2014, 111, 147-151. [CrossRef]

67. Mirabelli-Badenier, M.; Severino, M.; Tappino, B.; Tortora, D.; Camia, F.; Zanaboni, C.; Brera, F.; Priolo, E.; Rossi, A.; Biancheri, R. A novel homozygous MCOLN1 double mutant allele leading to TRP channel domain ablation underlies Mucolipidosis IV in an Italian child. Metab. Brain Dis. 2015, 30, 681-686. [CrossRef] 
68. Micsenyi, M.C.; Dobrenis, K.; Stephney, G.; Pickel, J.; Vanier, M.T.; Slaugenhaupt, S.A.; Walkley, S.U. Neuropathology of the Mcoln1(-/-) knockout mouse model of mucolipidosis type IV. J. Neuropathol. Exp. Neurol. 2009, 68, 125-135. [CrossRef]

69. Bonavita, S.; Virta, A.; Jeffries, N.; Goldin, E.; Tedeschi, G.; Schiffmann, R. Diffuse neuroaxonal involvement in mucolipidosis IV as assessed by proton magnetic resonance spectroscopic imaging. J. Child. Neurol. 2003, 18, 443-449. [CrossRef]

70. Geer, J.S.; Skinner, S.A.; Goldin, E.; Holden, K.R. Mucolipidosis type IV: A subtle pediatric neurodegenerative disorder. Pediatr. Neurol. 2010, 42, 223-226. [CrossRef]

71. Siegel, H.; Frei, K.; Greenfield, J.; Schiffmann, R.; Sato, S. Electroencephalographic findings in patients with mucolipidosis type IV. Electroencephalogr. Clin. Neurophysiol. 1998, 106, 400-403. [CrossRef]

72. Frei, K.; Patronas, N.; Crutchfield, K.; Brady, R.O.; Schiffmann, R. Magnetic resonance imaging in mucolipidosis type IV. J. Neuroimag. 1997, 7, 63.

73. Merin, S.; Nemet, P.; Livni, N.; Lazar, M. The cornea in mucolipidosis IV. J. Pediatr. Ophthalmol. 1976, 13, 289-295. [PubMed]

74. Goldin, E.; Caruso, R.C.; Benko, W.; Kaneski, C.R.; Stahl, S.; Schiffmann, R. Isolated ocular disease is associated with decreased mucolipin-1 channel conductance. Invest. Ophthalmol. Vis. Sci. 2008, 49, 3134-3142. [CrossRef] [PubMed]

75. Dobrovolny, R.; Liskova, P.; Ledvinova, J.; Poupetova, H.; Asfaw, B.; Filipec, M.; Jirsova, K.; Kraus, J.; Elleder, M. Mucolipidosis IV: Report of a case with ocular restricted phenotype caused by leaky splice mutation. Am. J. Ophthalmol. 2007, 143, 663-671. [CrossRef] [PubMed]

76. Pradhan, S.M.; Atchaneeyasakul, L.O.; Appukuttan, B.; Mixon, R.N.; McFarland, T.J.; Billingslea, A.M.; Wilson, D.J.; Stout, J.T.; Weleber, R.G. Electronegative electroretinogram in mucolipidosis IV. Arch. Ophthalmol. 2002, 120, 45-50. [CrossRef]

77. Lubensky, I.A.; Schiffmann, R.; Goldin, E.; Tsokos, M. Lysosomal inclusions in gastric parietal cells in mucolipidosis type IV: A novel cause of achlorhydria and hypergastrinemia. Am. J. Surg. Pathol. 1999, 23, 1527-1531. [CrossRef] [PubMed]

78. Modlin, I.M.; Goldenring, J.R.; Lawton, G.P.; Hunt, R. Aspects of the theoretical basis and clinical relevance of low acid states. Am. J. Gastroenterol. 1994, 89, 308-318.

79. Tellez-Nagel, I.; Rapin, I.; Iwamoto, T.; Johnson, A.B.; Norton, W.T.; Nitowsky, H. Mucolipidosis IV. Clinical, ultrastructural, histochemical, and chemical studiesof a case, including a brain biopsy. Arch. Neurol. 1976, 33, 828-835. [CrossRef]

80. Weitz, R.; Kramer, I.; Nissenkorn, I.; Shapira, Y.; Ben-David, E.; Kohn, G. Muscle involvement in mucolipidosis IV. Brain Dev. 1990, 12, 524-528. [CrossRef]

81. Goldin, E.; Blanchette-Mackie, E.J.; Dwyer, N.K.; Pentchev, P.G.; Brady, R.O. Cultured skin fibroblasts derived from patients with mucolipidosis 4 are auto-fluorescent. Pediatr. Res. 1995, 37, 687-692. [CrossRef]

82. Goebel, H.H.; Kohlschütter, A.; Lenard, H.G. Morphologic and chemical biopsy finding in mucolipidosis IV. Clin. Neuropathol. 1982, 1, 73-82.

83. Kenyon, K.R.; Maumenee, I.H.; Green, W.R.; Libert, J.; Hiatt, R.L. Mucolipidosis IV: Histopathology of conjunctiva, cornea and skin. Arch. Ophthalmol. 1979, 97, 1106-1111. [CrossRef] [PubMed]

84. Bargal, R.; Bach, G. Mucolipidosis type IV: Abnormal transport of lipids to lysosomes. J. Inherit. Metab. Dis. 1997, 20, 625-632. [CrossRef] [PubMed]

85. Philippart, M.; Kamensky, E. Chemical induction of lysosomal storage. Adv. Exp. Med. Biol. 1976, 68, 473-493. [PubMed]

86. Zeigler, M.; Bargal, R.; Suri, V.; Meidan, B.; Bach, G. Mucolipidosis type IV: Accumulation of phospholipids and gangliosides in cultured amniotic cells. A tool for prenatal diagnosis. Prenat. Diagn. 1992, 12, 1037-1042. [CrossRef] [PubMed]

(C) 2020 by the authors. Licensee MDPI, Basel, Switzerland. This article is an open access article distributed under the terms and conditions of the Creative Commons Attribution (CC BY) license (http://creativecommons.org/licenses/by/4.0/). 